\title{
Kulturskolen - et senter for samarbeid
}

\author{
Wenche Waagen
}

NTNU, Norges teknisk-naturvitenskaplige universitet

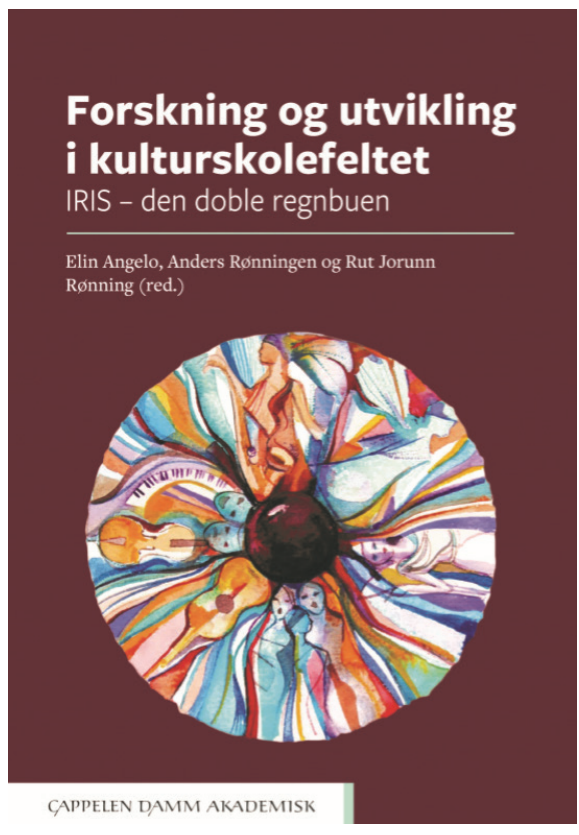

Elin Angelo, Anders Rønningen og Rut Jorunn Rønning (Red.). Forskning og utvikling $i$ kultur-skolefeltet, IRIS - den doble regnbuen. Cappelen Damm Akademsik. 277 sider.

Rammeplanen Mangfold og fordypning har skapt forventninger til kulturskolen som samarbeidsaktør med høyere utdanning, bl.a. ved å oppfordre til styrking av forskningsbasert og forskningsinformert undervisning i skoleslaget. Denne antologien møter nettopp denne oppfordringen; den er et resultat av møter mellom praksisfeltet og forskningsfeltet. Antologien inkluderer åtte vitenskapelige artikler og fem fagartikler på kulturskolefeltet i Norge, og er således både aktuell og kjærkommen. Forfattergruppa har bestått av forskere fra høyere utdanning, ph.d-studenter, masterstudenter og en forsker fra det utøvende musikkfeltet. Antologiens røde tråd er deres samlede fokus på kulturskolen som samarbeidspart: med grunnopplæringen, med frivillig og profesjonelt kulturliv, med foreldre, skoleledere og skoleeiere, og med private filantroper. 


\section{W. Waagen}

Antologien som er utgitt av Cappelen Damm Akademisk, består av 13 kapitler som spenner vidt. De springer ut av det omfattende IRIS-prosjektet, et kulturskoleutviklingsarbeid som foregikk i Buskerud, Vestfold og Telemark fra 2014-2016. Hver for seg viser kapitlene ulike forskende eller undersøkende innganger til kulturskolen som et forsknings- og fagfelt. Her finner vi eksempler på både musikkdidaktisk, profesjonsorientert og ledelsesfokusert forskning, supplert med bredde- og talentutvikling, organisasjonssamarbeid, krav til lærerkompetanse og musikk som inkluderingsverktøy. Allikevel framstår antologien som en samlet framstilling av hva forsknings- og fagfeltene knyttet til kulturskole kan være.

Kapitlene kan leses uavhengig av hverandre. Det er grunn til å trekke fram kapittel 2, av Rut Jorunn Rønning: «Hva er IRIS-prosjektet sitt bidrag i norsk kulturskoleutvikling?» Artikkelen er både en bakgrunnsartikkel for bokens tittel og de øvrige kapitlene, samtidig som den framstår som et reflekterende tilbakeblikk på IRIS-prosjektets betydning for kulturskoleutvikling i Norge. Den problematiserer hva som har bærekraft for framtidig kulturskoleutvikling, spørsmålet om elevenes sosiale bakgrunn og hvilke barn som fikk delta i prosjektet og forholdet mellom offentlig, privat eller filantropisk virksomhet på kulturskolefeltet.

Del 1 av antologien har et gjennomgående fokus på forholdet mellom kulturskolens fordypningstilbud og breddetilbud. Her finner vi flere kapitler med didaktiske innfallsvinkler: Kapittel 4, av Ellen M. Stabell og Anne Jordhus-Lier, drøfter for eksempel visjonen om et "breddefordypningsprogram» der flere elever får muligheten til fordypning i sitt kunstfag, og kapitlet problematiserer forholdet mellom talentutvikling og kulturskole for alle. I kapittel 5, «IRIS-prosjektet og Trondheimspyramiden", presenterer Andreas Viken premissene for en vellykket strykeopplæring der grunn-pilarene er nettverkssamarbeid rundt elevene og omfattende samspill på alle nivå: musikalsk, organisatorisk og kompetansemessig. I kapittel 6 presenterer Mari Ystanes Fjeldstad dikotomien «elevens individuelle og elevens kollektive kompetanse", der gruppeundervisningsformen fra kulturskolen og El Sistemas instrumentalpedagogiske praksis relateres til rammeplanen Mangfold og Fordypning. Kapittel 7, av Lise Lundh, kaster lys over vår tids aktuelle tematikk om hvordan kunstopplæring kan fungere inkluderende for marginaliserte elever, med flere praktiske eksempler. Her er instrumentalopplæring og skoleorkesteret sentral arena for mestring, elevers likever-dige stemmer og status. Kapitlet bør uten tvil leses av den som er opptatt av tilpasset opplæring.

Antologiens del 2 har et hovedfokus på samarbeidet mellom kulturskole og grunnskole. Kapittel 8, av Inger Anne Westby, er en analyse av hva som kjennetegner de to undervisningsfagene musikk i kulturskole og musikk i grunnskole, med påfølgende spørsmål om hvilken kompetanse læreren i kombinerte stillinger trenger for å mestre begge. Hennes utgangpunkt for å finne svar er læreplananalyser og intervju med musikklærere som kombinerer arbeid i skoleslagene. Brit Ågot Brøskes kapittel 12 handler også om forholdet mellom de to skoleslagene, men med den tanke-vekkende spørsmålsstillingen: Representerer dette forholdet ekspansiv læring eller bistandsarbeid? 
I kapittel 9, «Jeg vil bli kulturskolelærer når jeg blir stor», av Gry Sagmo Aglen og Sidsel Karlsen, utforsker forfatterne rammeplanens tre opplæringsprogrammer for å finne ut hvilken lærerkompetanse som synes ønskelig i disse, herunder hvilke kvalifiseringsveger som fins i norsk høyere utdanning. Dette er spørsmål mange kulturskolerektorer har stilt seg siden Mangfold og fordypning kom i 2016.

Kulturskoleledere vil også kunne ha utbytte av kapittel 11, av Elin Angelo og Anne Berit Emstad. På basis av intervjuer analyserer forfatterne her hva kulturskolerektorer, skolesjefer, rådmenn og kulturaktører tenker om samarbeid, hvilken kunnskap samarbeidet skal forvalte, organisering, ressursbruk og lærerkvalifikasjoner. Ledelse er også tematikk i kapittel 3, av Erlend Dehlin og Pia Skog Hagerup, der artist talk som metode viser hvordan et samtalekonsept kan være en kvalitativ forskningsmetode. Wolfgang Plagge er her samtalepartner, en kunstner i lederrolle, som på en kreativ og godt artikulert måte bruker kunstbegrepet til å belyse skoleledelse som generelt fenomen, med fokus på fem vitale hoveddimensjoner.

For den som er interessert i høringsprosesser som del av det demokratiske Norge og hvilke tematikker som framsto som viktige i løpet av Norsk Kulturskoleråd sin høringsrunde på ny rammeplan, belyses dette av Halvor Bjørnsrud og Anders Rønningen i kapittel 10: «Forskende partnerskap som grunnlag for fagplanhøring og utviklingsprosesser i kulturskolen - erfaringer når kulturskoler vurderer innhold i den nye læreplanen».

Faglig og forskningsmessig er antologien solid. Forskningsartiklene har en innramming av metode, teoretisk tilnærming, forskningsdesign, referanser og funn i undersøkelsene. Dette i seg selv kan fungere som døråpner til læreres og lederes selvinitierte utforsking av læring og undervisning i kulturskolen, eller inspirere til nye samarbeid med høyere utdanning. I beste fall vil det kunne bringe ny kunnskap om hva utviklingsarbeid på feltet kan være, hvordan det kan gjennomføres, oppsummeres og publiseres. Antologien er skrevet på et høyt akademisk nivå, og studenter innen kunstfag bør ha gode forkunnskaper om forskningsmetode og kulturskolen som skoleslag og samfunnsinstitusjon, for å ha fullt utbytte av den.

En lukker boka med undertittelen i mente: IRIS - den doble regnbuen: Den greske gudinnen IRIS var bindeleddet mellom gudeverdenen og menneskene. Tilsvarende er kulturskolene bindeleddet mellom elevenes grunnopplæring, deltakelse i fritidskulturlivet, kvalifisering til høyere utdanning og yrkesliv. Og i enden av regnbuen ligger det alltid en skatt: kunstopplæringens skjønnhet og forskningens systematikk.

\section{Referanse}

Angelo, E., Rønningen, A., \& Rønning, R. J. (2017). Forskning og utvikling i kulturskolefeltet. IRIS - den doble regnbuen. Oslo: Cappelen Damm Akademisk. DOI: https://doi.org/10.23865/noasp.21 